\title{
PENGARUH PENGGUNAAN MEDIA PEMBELAJARAN INTERAKTIF BERBASIS ANDROID TERHADAP HASIL BELAJAR SISWA
}

\author{
Ketut Sepdyana Kartini ${ }^{1}$ dan I Nyoman Tri Anindia Putra ${ }^{2}$ \\ Program Studi Teknik Informatika, STMIK STIKOM Indonesia \\ Email : sepdyana27@gmail.com ${ }^{1}$, trianindiaputra@gmail.com ${ }^{2}$
}

\begin{abstract}
ABSTRAK
Penelitian ini bertujuan untuk mengetahui pengaruh implemetasi media pembelajaran interaktif berbasis android terhadap hasil belajar siswa pada materi tata nama IUPAC senyawa anorganik di SMAN 4 Denpasar. Metode penetilian yang digunakan adalah pretest-posttes group desain dengan sistem pengambilan sampel menggunakan cluster random sampling. Subjek penelitian terdiri dari 2 kelas yaitu kelas XI MIPA 3 sebagai kelas kontrol dan kelas XI MIPA 4 sebagai kelas eksperimen. Perlakukan pada dua kelas sampel dibedakan dengan implementasi media pembelajaran interaktif berbasis android pada kelas eksperimen sedangkan kelas kontrol tidak. Intsrumen yang digunakan adalah instrument tes soal uraian. Hasil penelitian menunjukkan bahwa uji t terhadap hasil belajar dengan diperoleh $t_{\text {hitung }}$ $=1,87$ lebih besar dari $t$ tabel $=1,67$ di dukung dengan nilai $\mathrm{N}$-gain dari kelas eksperimen sebesar 0,74 dibandingkan kelas kontrol. Selain itu hasil penelitian implementasi media pembelajaran interaktif berbasis android memiliki pengaruh sebesar $62,72 \%$ terhadap hasil belajar siswa.
\end{abstract}

Kata Kunci : Android, Hasil belajar siswa, Media pembelajaran

\section{PENDAHULUAN}

Dalam proses belajar mengajar, model pembelajaran sangat mempengaruhi hasil dari proses tersebut. Banyak model pembelajaran yang bisa digunakan dalam proses belajar yang mampu mendukung hasil belajar terhadap siswa. Perkembangan dalam dunia pendidikan saat ini sudah sampai pada model pembelajaran yang menggunakan sentuhan teknologi dalam pelaksanaannya. Hal tersebut diikuti berdasarkan perkembangan siswa yang saat ini sudah berada pada generasi milenial. Pada generasi milenial karakter dari siswa yang selalu ingin cepat baik dalam proses pembelajaran seperti pencarian informasi, tugas, materi, dan sebagainya membuat model pembelajaran mau tidak mau harus menggunakan teknologi sebagai sarana dalam proses pembelajaran didalamnya.

Salah satu pembelajaran yang ada pada sekolah adalah materi pelajaran kimia. Materi ini merupakan salah satu materi yang cukup kompleks dilihat dari aspek cara pemahamannya yang tidak hanya didasari oleh teori saja, akan tetapi pembelajaran ini harus dikaji dengan 3 aspek diantaranya simbolik, makroskopis, dan mikroskopis. Kimia memiliki konsep yang bersifat abstrak, memiliki perhitungan serta rumus yang banyak, sehingga mata pelajaran kimia ini menjadi sulit untuk dimengerti siswa dan berpengaruh pada hasil belajar[1]. Nilai rata-rata kimia siswa pada SMAN 4 Denpasar adalah 65 yang memiliki persentase sebesar $60 \%$ dimana siswa belum tuntas dalam belajar. Hal ini didapat dari hasil penelitian [2] yang menyatakan bahwa hasil dari proses belajar siswa pada materi kimia ini dikategorikan dengan kategori rendah. Hal ini tidak lepas dari model pembelajaran serta guru yang memberikan proses belajar mengajar.

Model pembelajaran yang semakin berkembang mengakibatkan kreatifitas insang di dunia pendidikan harus selalu berkembang ditengah generasi milenial yang selalu ingin cepat berdasarkan penelitian [3]. Media pembelajaran berbasis mobile merupakan salah satu model pembelajaran yang sangat efektif digunakan terutama dalam proses belajar mengajar siswa secara mandiri berdasarkan hasil penelitian [4]. Selain memberikan tampilan gambar yang menarik, juga memberikan pengalaman belajar bagi siswa untuk belajar dimana saja dan kapan saja [5]. Generasi siswa saat ini yaitu generasi milenial yang memiliki karakter ingin 
cepat dalam mengakses apapun termasuk pembelajaran sangat cocok menggunakan model pembelajaran dengan sentuhan teknologi seperti media pembelajaran berbasis mobile [4]. Dalam proses belajar mengajar juga diperlukan suasana yang baik dan kondusif [6].

Dalam meningkatkan proses dari hasil belajar yang dilakukan oleh siswa sehingga diperlukan suatu model pembelajaran dalam proses belajar mengajar salah satunya dengan memanfaatkan teknologi pembelajaran berupa media pembelajaran yang mampu meningkatkan hasil belajar siswa serta mampu digunakan kapanpun dan dimanapun oleh siswa. Meningkatkan minat siswa dalam belajar juga menjadi aspek penting dalam memperoleh hasil belajar yang maksimal. Dalam penelitian ini akan berfokus pada pengaruh penggunaan media pembelajaran interaktif berbasis android terhadap hasil belajar dari siswa. Dimana siswa secara mandiri dapat meningkatkan pengetahuannya serta guru hanya sebagai seorang pembimbing atau fasilitator [7].

\section{METODE}

Penelitian ini menggunakan pretest-posttes group desain dengan metode pengambilan sampel dengan cara cluster random sampling. Variabel bebas dalam penelitian ini adalah data hasil pretest dan posttest dari kelas eksperimen dan kelas kontrol.

Sampel dalam penelitian ini adalah kelas XI MIPA 4 sebagai kelas kelas eksperimen dengan implementasi media pembelajaran berbasis android dan kelas XI MIPA 3 sebagai kelas kontrol tanpa perlakuan. Metode pengumpulan data yang dilakukan dengan metode tes uraian/ berupa soal essay. Yang mana, data hasil belajar kognitif dihitung dengan uji homogenitas dan normalitas, uji kesamaan dua varians, uji t, uji N-gain, analisis pengaruh antar variabel, dan penentuan koefisien determinasi [1]. Pengujian tersebut bertujuan untuk mengetahui pengaruh dan seberapa besar pengaruh penggunaan media pembelajaran berbasis aplikasi android terhadap hasil belajar siswa.

\section{HASIL DAN PEMBAHASAN Hasil}

Media pembelajaran interaktif berbasis android memiliki beberapa tampilan menu yaitu, halaman materi, halaman latihan soal dan halaman kuis. Berikut beberapa tampilan menu aplikasi android yang digunakan dapat dilihat pada Gambar 1

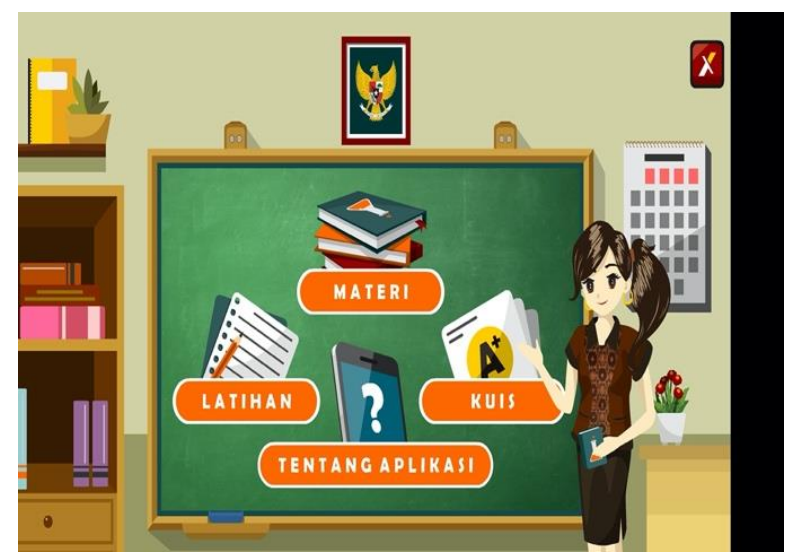

(a)

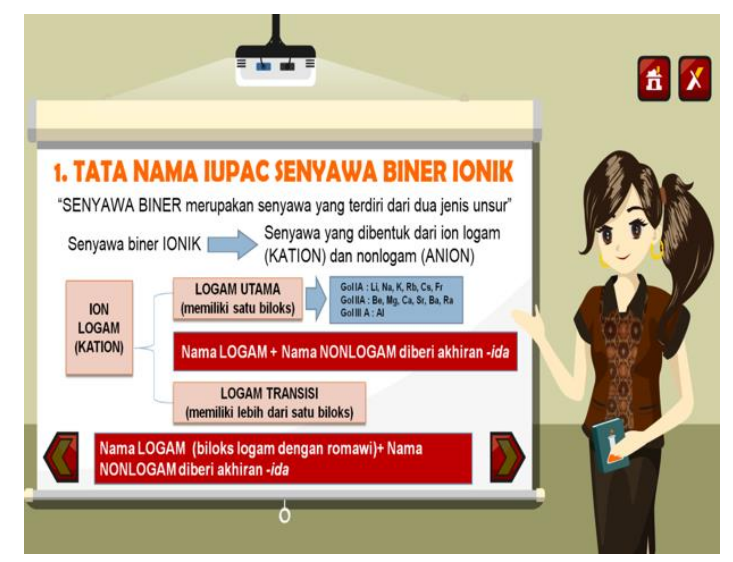

(b) 


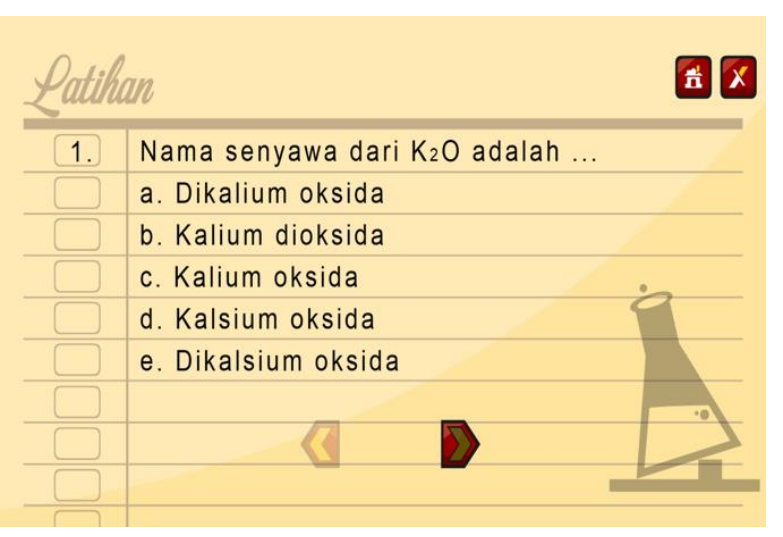

(c)

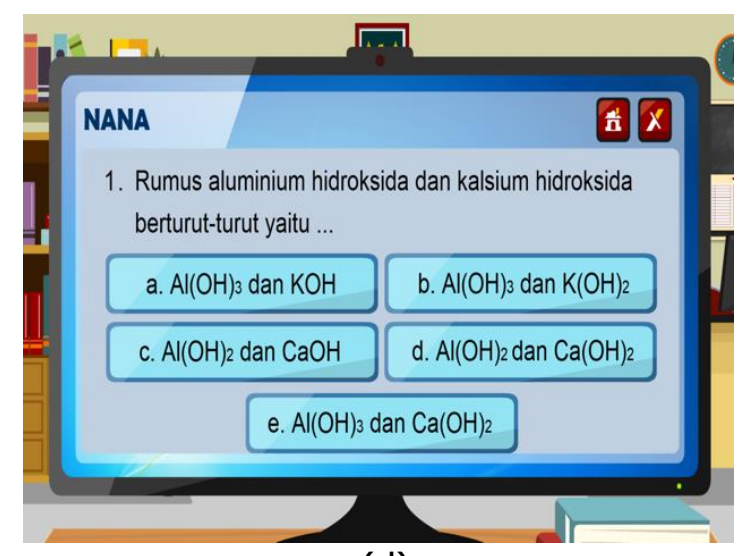

(d)

Gambar 1. (a) tampilan menu utama, (b) tampilan menu materi, (c) tampilan halaman latihan soal, (d) tampilan halaman kuis

Kegiatan belajar mengajar dilaksanakan sesuai dengan RPP yang terbagi menjadi 5 pertemuan. Yang mana, di pertemuan awal siswa diberikan pretest yang telah diuji cobakan dan dihitung validitasnya. Pertemuan selanjutnya di lakukan kegiatan belejar mengajar dengan perlakuan berbeda terhadap kedua kelas sampel. Kelas eksperimen diberikan perlakuan pembelajaran dengan menggunakan media interaktif berbasis android sedangkan kelas kontrol tidak menggunakan media pembelajaran berbasis android. Tahap pertemuan akhir baik kelas eksperimen maupun kelas kontrol diberikan posttest untuk mengetahui seberapa besar perubahan aspek kognitif siswa setelah diberi perlakuan. Rata-rata nilai pretest dan posttest siswa dapat dilihat pada Gambar 2

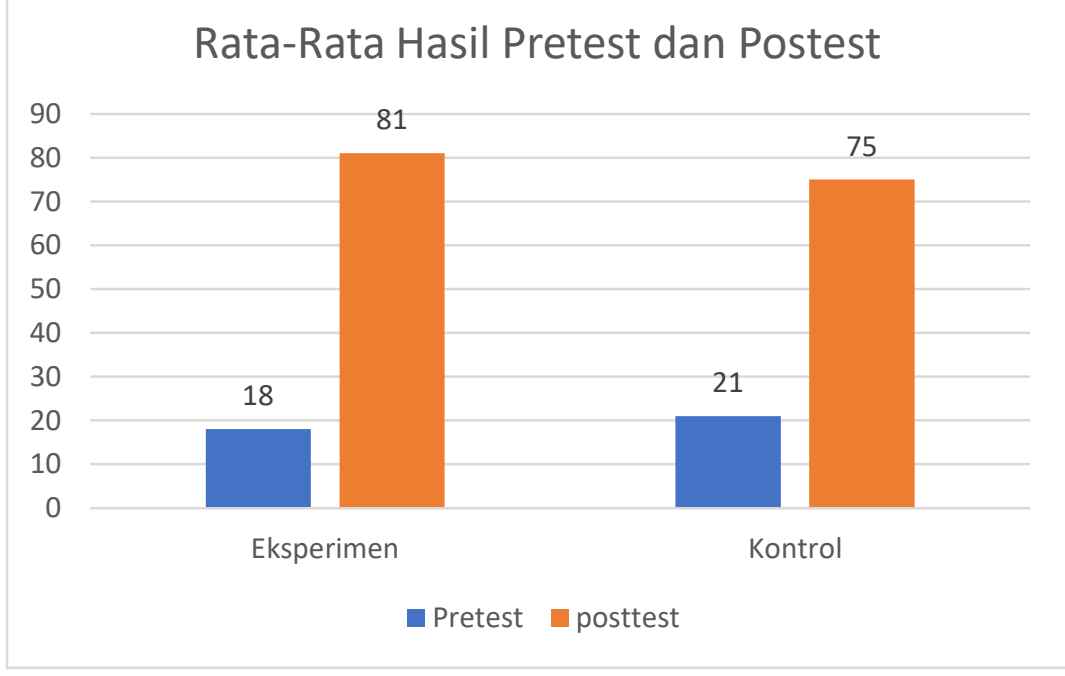

Data yang didapat dari hasil pretest dan posttest sebelum diuji hipotesisnya dilakukan pengujian tahap awal yaitu pengujian normalitas, homogenitas dan uji kesamaan dua varians. Data hasil perhitungan uji homogenitas dan uji normalitas dapat dilihat pada Tabel 1.

Tabel 1. Hasil Uji Normalitas dan Homogenitas

\begin{tabular}{cccccc}
\hline \multirow{2}{*}{ No } & \multirow{2}{*}{ Kelas } & \multicolumn{2}{c}{$\mathbf{X}^{\mathbf{2}}$ hitung } & \multirow{2}{*}{$\mathbf{X}^{\mathbf{2}}$ tabel } & \multirow{2}{*}{ Keterangan } \\
\cline { 3 - 4 } & & Pretest & Posttest & & \\
\hline 1 & Eksperimen & 6,34 & 3,52 & & Normal/Normal \\
2 & Kontrol & 8,17 & 4,26 & \multirow{2}{*}{12,45} & Normal/Normal \\
& Homogenitas & 6,79 & 1,29 & & Homogen/Homogen \\
\hline
\end{tabular}


Pengujian selanjutnya adalah menghitung koefisien biserial dan koefisien determinasi untuk mengetahuiseberapa besar pengaruh media interaktif berbasis android terhadap hasil belajar siswa yang digambarkan pada Gambar 3.

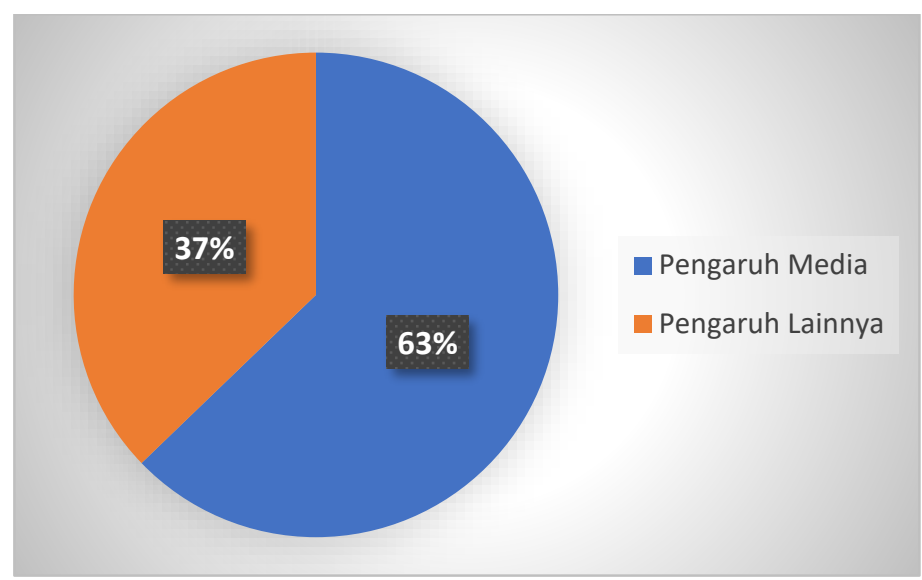

Gambar 3. Persentase Koefisien Determinasi

\section{Pembahasan}

Berdasarkan hasil penelitian hasil pretest dan posttest pada Gambar 2 menunjukkan adanya perbedaan yang signifikan. Hasil pretest kelas eksperimen memiliki rata-rata nilai sebesar 15,13 lebih kecil dibandingkan dengan rata-rata nilai pretest kelas kontrol yaitu sebesar 20,35. Rata-rata nilai posttest yang didapat kelas eksperimen 71,30 dan lebih besar dibandingkan dengan rata-rata nilai posttest kelas kontrol yaitu sebesar 65,54.

Selanjutnya, berdasarkan hasil pengujian koefisien biserial dan koefisien determinasi untuk mengetahui seberapa besar pengaruh implementasi media interaktif berbasis android terhadap hasil belajar siswa. Hasil perhitungan koefisien korelasi biserial dan koefisien determinasi dari data posttest diperoleh untuk koefisien korelasi sebesar 0,74 dan koefisien determinasi sebesar $62,72 \%$. Hal ini menunjukkan adanya pengaruh penggunaan media pembelajaran berbasis aplikasi android secara signifikan terhadap hasil belajar siswa walaupun perbedaan nilai terendah dan nilai tertinggi dari kedua kelas tersebut tidak terpaut terlalu jauh. Hasil belajar siswa juga dipengaruhi oleh beberapa faktor lain yang ditunjukkan dalam presentase koefisien determinasi sebesar 37,28 \% diantaranya adalah faktor guru, fasilitas yang tersedia, faktor sosial baik di lingkungan sekolah maupun di luar sekolah, dan juga faktor interen siswa seperti motivasi, kemauan dan lain sebagainya [2].

\section{KESIMPULAN}

Berdasarkan hasil penelitian yang telah diuraikan, dapat disimpulkan bahwa implementasi media interaktif berbasis android terhadap hasil belajar siswa pada materi tata nama IUPAC senyawa anorganik terdapat perbedaan yang signifikan antara rata-rata hasil belajar siswa kelas kontrol dan kelas eksperimen yang ditunjukkan dengan uji t dengan thitung sebesar 1,87 yang lebih besar debandingkan dengan ttabel sebesar 1,67 yang berada pada daerah penolakan Ho dan nilai $\mathrm{N}$-gain dengan selisih yang cukup besar. Sehingga, kelas eksperimen dengan penggunaan media pembelajaran interaktif berbasis android memiliki pengaruh yang signifikan pada hasil belajar siswa yang ditunjukkan dengan harga koefisien korelasi biserial sebesar 0,74 dan koefisien determinasi sebesar $62,72 \%$ dengan kategori signifikan. 


\section{DAFTAR PUSTAKA}

[1] S. Arikunto, "Prosedur Penelitian suatu Pendekatan Praktek edisi revisi VI Jakarta:: Rineka Cipta," Arsyad, A (2005). Media Pembelajaran. Jakarta. PT Raja Graf. Persada, 2006.

[2] S. Sudarmin and I. F. Azizah, "Kontribusi Media Interaktif Pada Contextual Teaching And Learning Berorientasi Learning Community Terhadap Hasil Belajar Kimia," J. Inov. Pendidik. Kim., vol. 6, no. 1, 2012.

[3] I. N. Tri, A. Putra, K. S. Kartini, and N. N. Widiyaningsih, "IMPLEMENTASI MEDIA PEMBELAJARAN INTERAKTIF BERBASIS MOBILE PADA MATERI HIDROKARBON," vol. 4, no. 2, pp. 43-52, 2020.

[4] K. S. Kartini and I. N. T. A. Putra, "Respon Siswa Terhadap Pengembangan Media Pembelajaran Interaktif Berbasis Android," J. Pendidik. Kim. Indones., vol. 4, no. 1, p. 12, 2020.

[5] K. S. Kartini and I. K. Setiawan, "Pengembangan Media Pembelajaran Interaktif Tata Nama Iupac Senyawa Anorganik Berbasis Android," Pendidik. dan Pembelajaran, vol. 3, pp. 238-245, 2019.

[6] I. E. Nurrokhmah and W. Sunarto, "Pengaruh penerapan virtual labs berbasis inkuiri terhadap hasil belajar kimia," Chem. Educ., vol. 2, no. 2, 2013.

[7] R. S. Putra, N. Wijayati, and F. W. Mahatmanti, "Pengaruh penggunaan media pembelajaran berbasis aplikasi android terhadap hasil belajar siswa," J. Inov. Pendidik. Kim., vol. 11, no. 2, 2017. 